\title{
Comparing metabolic regulation systems in wine yeasts with employment systems in economic wine industry
}

\author{
M. Grossmann and M. Waldeck ${ }^{\mathrm{a}}$ \\ Hochschule Geisenheim University Von-Lade-Straße 1, 65366 Geisenheim, Germany
}

\begin{abstract}
The main aim of each living organism is to live, to survive to detrimental environmental conditions and to reproduce, forming the next generation. A very similar aim is valid for an enterprise striving for commercial and financial success as well as for survival and longevity. This article sums up essential strategies for both of these two very different types of organizations, comparing biological systems that have developed over millions of years with employment systems in the modern economic world. The outcome displays some unexpected features of similarities.
\end{abstract}

\section{Introduction}

Adaptation and survival of microorganisms under given environmental conditions is only guaranteed when cellular regulation systems respond quickly and efficiently to external factors. The survival of enterprises in production and trade also depends on their ability to rapidly adapt to changing economic conditions. By comparing the respective systems it will be shown how evolution of microbial regulatory mechanisms since millions of years find their counterparts in modern economic systems of enterprises.

The most important yeast species in the wine making process is named "Saccharomyces cerevisiae", that ferment grape must into wine. It's a unicellular microorganism that cannot be seen with the naked eye, as the cell diameter is 12 to 14 micrometer. Because of these minute dimensions the relation between the internal cell volume and the surrounding cell surface is dramatically high.

This tremendous surface area makes it necessary to establish very efficient transfer systems that selectively transport compounds inside the cells that are necessary for cell growth. In the case of grape must fermentation examples are sugar (glucose and fructose), amino acids and vitamins. On the other hand, the end products of the alcoholic fermentation: alcohol (ethanol) and carbon dioxide $\left(\mathrm{CO}_{2}\right)$ must also be very efficiently exported out of the cell otherwise these compounds would be toxic for yeasts and kill them.

All imported substances must also be used very efficiently otherwise the yeast cell would face starvation and finally cell death.

Yeast cell metabolism must therefore be strictly regulated in such a way that necessary compounds should not be synthesized at the expense of energy when they are present outside and easily taken up. Furthermore only those substances not present in the surrounding medium should be cell internally produced. Only these

a e-mail: Manfred.Grossmann@hs-gm.de compound production lines should be active as they always need energy which is only present in a limited amount. Therefore high demand for rigorous regulation is always present. Important regulation systems for efficient cell metabolism are shown in a large number of publications [for reviews see 1-3].

Cellular production lines do exist because there's a sequence of bio-catalysts (enzymes) where each enzyme catalyzes only one particular biochemical reaction. The sequence of different enzymes and their highly regulated collaboration determine the amount of the wanted/necessary end product of such a specific production line. Wine yeasts are working day and night during fermentations in changing environments (different grape musts) which needs hundreds and thousands of individual biochemical reactions running at the same time and performed by enzymes.

Enzymes are the "workers" in a cell metabolism and form by this fact the link to workers/employees in commercial enterprises.

The economic success of every company is always also a question of employing people and what they cost. Selling price depends on different factors where cost price and profit margin are important variables. Costs arise among others from labor costs, material costs (if necessary) and overhead costs. Costs of labor can directly be compared with the costs for enzymes, not in terms of money but in terms of needed energy and material to build them. If too many enzymes of a certain type are produced or if they are produced for a production line which end product is then needed to a lower extent by the yeast cell, stringent regulations must take place or the yeast cell will perish. Same situation will take place in a firm if the demands for certain products decline and the number of employees is then too high to remain profitable $[4,5]$.

\section{Results and discussion}

The following text shows at first the principal cellular regulation systems that are operating in yeasts, then 


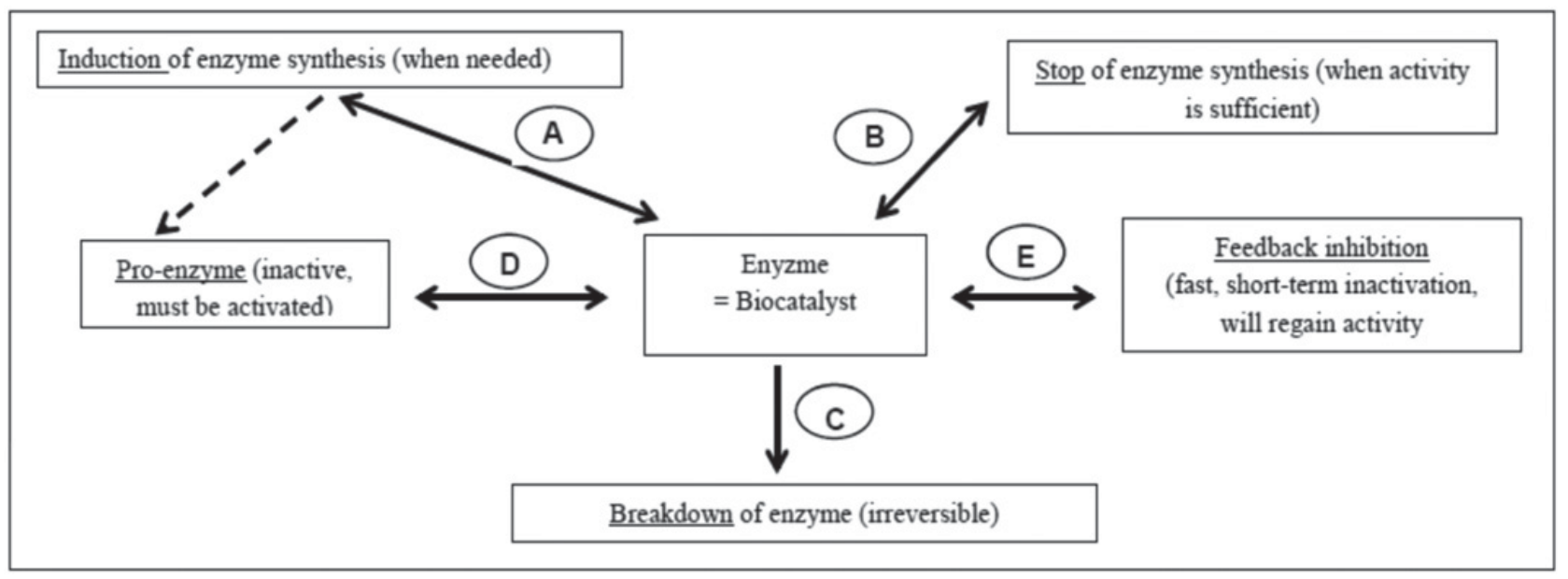

Figure 1. Types of regulating enzyme activity. Leg.: Letters refers to explanation in the text.

followed by a comparison with economic systems used in the wine industry.

\subsection{Regulations systems in yeasts}

Wine yeasts live and have to survive in an always changing environment, especially during alcoholic fermentations. Accordingly compounds necessary for building new cells are sometimes present in the grape must, but sometimes not, so it's extremely important to produce them cell internally in a short period of time. This shows how very adaptable yeast cells have to regulate their metabolism either building up needed compounds at the expense of energy, or by saving energy just taking up compounds from the outside, if available.

The principal mechanisms by which yeasts regulate their metabolism in an optimal manner are given in Fig. 1. Basically, enzymes also named biocatalysts are the "working elements" in each living cell, independent whether it's a microorganism, plant, animal or human. Each enzyme is characterized by the fact that it can only recognize one certain compound (= substrate specificity) which the enzyme transfers in a very specific way to a product (= reaction specificity/enzyme specificity). For example, if a final compound that is needed in a yeast cell and has to be build up from a basic compound with the need for 10 different biochemical reaction steps, then ten different enzymes have to be active. Each enzyme itself has a relatively complex structure and is composed by several hundreds of sub-compounds (amino acids) which are merged together in a very specific and energy consuming sequence.

In general, a properly functioning cell metabolism depends on the one hand on the controlled synthesis of necessary compounds like vitamins, fatty acids etc. and on the other hand on the controlled synthesis of enzymes necessary for producing exactly these compounds. And these production pathways have to be tightly regulated as they are highly energy dependent. If energy is wasted in producing enzymes that are not needed, the result would be cell starvation and finally cell death. To avoid all this, with the letters A to E in Fig. 1 the background of each regulation step will be explained by which yeast cells do efficient fine-tuning of cell metabolism.

\section{A: Induction of enzyme synthesis}

Glucose and fructose are the sugars that are present in grapes and grape musts. Especially in cool climate regions because of difficult weather conditions, it might be necessary to do chaptalization. The added sugar sucrose is a disaccharide composed of glucose and fructose that cannot be taken up into the yeast cells. It must be split into the two monosaccharides. This cleavage can only be done by the action of an enzyme that is called invertase, normally not present in yeast when sucrose is absent. As soon as yeast cells recognize that sucrose as a fermentable and energy yielding compound is present in grape must then the synthesis of these highly needed enzyme molecules is induced and the final enzyme transported to the cell wall, where it is incorporated, splitting sucrose on the outside. Glucose and fructose are then easily taken up.

\section{B: Stop of enzyme synthesis (repression)}

Many enzymes are continuously synthesized as their activity is permanently needed. For example, yeasts sitting on grape skin cannot take up enough amino acids or vitamins from the outside, therefore there is always the need for synthesis of required enzymes, all processes performed at the expense of energy. As soon as yeasts are in contact with grape must after the pressing process, enough of these compounds are present, therefore no further demand for these compounds and the relevant enzymes exist.

Within short time further synthesis of all these enzymes is stopped and a process called repression takes place to avoid energy depletion.

\section{C: Breakdown of enzyme}

All enzymes in a yeast cell are present for a limited time period. Due to their steady work their activity decreases slowly and because of that they must be replaced (turnover). As synthesis of enzymes needs a lot of amino acids, these compounds are therefore of high value. To protect this value, enzymes no longer needed are broken down by specific enzymes (proteases and peptidases) into amino acids which can then be used again, perfect recycling process. 


\section{D: Pro-enzyme}

Pro-enzymes or pre-enzymes are enzymes that are formed, but present in a non-active form. Such enzymes can be found in a category of yeast enzymes that are secreted out of the cells and activated during the secretion process to avoid unwanted reaction inside the yeast cell. Enzymes formed that way can also be found in the regulation of phospholipid metabolism.

\section{E: Feedback inhibition}

Letter B "Stop of enzyme synthesis", also called repression, represents the situation that no new enzyme molecules are formed. However the existing ones are still present for a certain period of time. Within that duration the activities of these enzymes could be very harmful for the yeasts as they might catalyze reactions that consume a lot of energy, which got lost unnecessarily and might cause cell starvation. So, rapid action is needed to stop the unwanted enzyme activities. This is why a highly regulated mechanism was developed within millions of years of evolution.

The metabolism of living organisms has a high demand especially for amino acids, the basic compounds for synthesis of enzymes. About 20 different amino acids are needed. Their synthesis is not organized in a way that each amino acid has its own synthesizing pathway but cell metabolism shows a few main pathways which branch at different sites into side chains leading to the needed final amino acids. So, a high degree of effectiveness is achieved as only at distinct biochemical reaction steps these side pathways are starting. As soon as enough product of a given pathway is present, this end product attaches to the first enzyme of the side pathway. By this action so this enzyme activity decreases significantly. The flow within this side pathway slows down within seconds resulting in an extremely low further production of this end product. The end product therefore becomes an inhibitor of its own synthesis. With this feedback inhibition mechanism a very fast regulation system exists showing two advantages: firstly, fast inhibition of further amino acid synthesis and secondly, when the cell recognizes that there is again a need for this amino acid then the inhibitor is released from the enzyme. As a result the enzyme regains its activity and very rapidly new end product/amino acid is produced again.

Having seen the principal cell regulation mechanisms in yeasts, the question is whether these systems find their counterparts in wine economy or not?

\section{Comparison of regulation mechanisms in yeasts and in wine economy}

Existence and survival of yeast cells as well as that of companies in the wine industry depends primarily on how fast each of them can respond to a changing environment. Table 1 displays nine cases where microbial systems are compared with efficient work in an enterprise [6].

\section{Case 1: Enzymes vs. employees/workers}

Living cells as well as operating companies need work force. Enzymes as catalysts enable biochemical reactions by converting a specific substrate is into a specific,
Table 1. Comparing yeast regulation systems with economic employment relationships.

\begin{tabular}{|c|c|c|}
\hline Case & Yeast metabolism & Economic system \\
\hline 1 & $\begin{array}{l}\text { Enzymes and } \\
\text { activities }\end{array}$ & Employees/workers \\
\hline 2 & $\begin{array}{l}\text { Time limited presence } \\
\text { of enzymes; } \\
\text { replacement by new } \\
\text { ones with same } \\
\text { specificity }\end{array}$ & Shift-working \\
\hline 3 & $\begin{array}{l}\text { metabolic pathways } \\
\text { by sequence of } \\
\text { different enzymes }\end{array}$ & Assembly-line work \\
\hline 4 & Constitutive enzymes & Permanent position \\
\hline 5 & $\begin{array}{l}\text { Regulation: enzyme } \\
\text { activities on demand }\end{array}$ & $\begin{array}{l}\text { Regulation: work } \\
\text { force on demand }\end{array}$ \\
\hline 5.1 & $\begin{array}{l}\text { Induction of enzyme } \\
\text { synthesis }\end{array}$ & $\begin{array}{l}\text { Engagement of new } \\
\text { personnel (numerical } \\
\text { flexibility) }\end{array}$ \\
\hline 5.2 & $\begin{array}{l}\text { Repression of enzyme } \\
\text { synthesis }\end{array}$ & Hiring freeze \\
\hline 5.3 & $\begin{array}{l}\text { Activation of } \\
\text { "dorming" enzymes } \\
\text { (pro-enzymes) }\end{array}$ & $\begin{array}{l}\text { Reactivation of } \\
\text { former employees }\end{array}$ \\
\hline 5.4 & $\begin{array}{l}\text { Transient inactivation } \\
\text { of enzymes }\end{array}$ & V-time working \\
\hline 5.5 & $\begin{array}{l}\text { Active breakdown of } \\
\text { existing enzymes }\end{array}$ & $\begin{array}{l}\text { Dismissal of } \\
\text { employees (numerical } \\
\text { flexibility) }\end{array}$ \\
\hline
\end{tabular}

desirable product. An enzyme has a substrate specificity and a reaction specificity that allows to work with one very specific compound and only one mode of action with this compound. Employees/workers on the other hand are normally not so much specialized like an enzyme:

workers appointed for wine making have as original "substrate" grapes but they can do numerous operations in the processing of the grapes to bottled wine. On the other hand looking at computer specialists working in big cooperatives or international companies they are often highly specialized in what they are doing, so their working field as "substrate specificity" is much more restricted and thereby closer to what enzymes are doing.

\section{Case 2: Time limited presence of enzymes vs. shift- working}

Enzymes are present and active for a relatively short time within a yeast cell (approx. $30 \mathrm{~min}$ ) as they are loosing activity gradually. They are therefore replaced by newly synthesized enzymes of the same type. This behavior is very close to shift-working in big wineries for example during the harvest season where incoming grapes have to be pressed independent whether it's day or night. Shiftworking will guarantee that the grape processing is running without problems due to tired workers.

\section{Case 3: Metabolic pathways by sequence of different enzymes}

Many compounds required by yeast cells are not present in the surrounding medium and must be produced 
internally. These anabolic (synthesizing) pathways are often composed as a sequence of 10 to 30 different individual biochemical reaction steps. Each step is catalyzed by one special enzyme (see case 1 ). Therefore one reaction follows the other which is absolutely the same as in an assembly-work line. Although this is more the situation in technical enterprises, we also find this situation in small wineries when it comes to the different steps of the bottling process.

\section{Case 4: Constitutive enzymes vs. permanent position}

Taking the alcoholic fermentation as example, it is clear that all enzymes necessary for the conversion of grape sugars (glucose and fructose) to alcohol (ethanol) and carbon dioxide must be present at all times. Therefore they are continously produced, addressed as constitutive synthesis. Therefore no induction and repression mechanisms are necessary (see Fig. 1). Again a strong comparability with employees in a winery, for example with a core team in wine cellar, administration and wine sale is given.

\section{Case 5: Regulation: Enzyme activity on demand vs. work force on demand}

The following regulation systems are of extreme importance for survival of yeast cells in problematic grape juices as well as survival of wine enterprises facing difficult market conditions. See also explanation with Fig. 1.

\section{Case 5.1: Induction of enzyme synthesis vs. engagement of new personnel}

As soon as a valuable energy delivering compound is recognized by yeasts to be present outside the cell, then the synthesis of all enzymes necessary to metabolize these compounds is switched on. This system is working as long as the compound is present. Similar situation can happen in a winery when, due to very positive weather conditions, the amount of grapes to be harvested increases significantly. Then new workers for vineyards and cellar have to be appointed.

\section{Case 5.2: Stop/repression of enzyme synthesis vs. hiring freeze}

Case 5.1 shows what is happening when work force is needed. However as soon as this need is no longer existing then still continuous synthesis of these special enzymes and also still ongoing hiring of people would cause tremendous problems as their work force is not needed anymore. Yeast cells as well company manager will immediately stop these processes. Yeasts as well as managers use this system of numerical flexibility.

\section{Case 5.3: Activation of "dorming" enzymes (pro- enzymes}

Some enzymes especially those located on the outside of the yeast cell wall, like invertases, are often produced in an inactive status but activated when needed on their way to the outside. This system doesn't find a real 1:1 comparability with work in a winery besides the possibility that former employees can be "reactivated" for high seasons in wine selling, for example.

\section{Case 5.4: Transient inactivation of enzymes vs. V-time working}

In some pathways of cell metabolism the yeast cell must react quickly to changing external conditions. This is especially important when an end product that is needed but produced with high energy consumption is now present externally and can easily be taken up. If that happens yeast can not only stop synthesis of enzymes (see case 5.2) but they stop activity of certain enzymes as these bind the end product they normally produce. So, this is a very fast response. Same system is also working in a winery, when for example when a low yield in ripe grapes can be handled by a reduced number of people. In that case dismissing of people wouldn't make sense as a bit later workers with their experience are necessary again. Therefore the V-time working systems is appropriate where employees agree voluntarily to reduce their working hours for some time and then come back to full employment when the situation has changed to normal again.

\section{Case 5.5: Active breakdown of existing enzymes vs. dismissal of employees}

Enzymes that are no longer needed and also not expected to be needed again are actively broken down. When the economic situation in a winery unfortunately predicts that wine sale will decline for a long or unforeseeable time then dismissal of employees is unavoidable to improve the economic situation and the survival of the company.

In summary, independent whether it's a yeast cell or a wine producing company each wants to survive now and in the future. To achieve this, yeasts as well as companies need therefore mechanisms to react to changing external conditions. Looking at positive external conditions the reaction of yeasts should result in higher number of daughter cells (next generation) and wine companies should gain higher profit. However as soon as external conditions become worse, yeasts and wine companies react in significantly similar mechanisms as both get rid of enzymes (yeast side) and workers (wine business side) to overcome such a situation. The only striking difference between yeast and wine company is the flexible employment system where employees can work in other parts of a winery as they normally do for a certain period of time. Enzymes do not have this flexibility as they can only do one strict type of biochemical reaction.

This short article can be seen as entrance to further comparisons between microbial and economic regulation systems. Another interesting approach will include a look into the microbial signaling mechanisms which serve as rapid indicators of a changing environment. Fast recognition of forthcoming changes in the economic environment within the wine business are of high importance. If changes in consumer expectations and drinking behavior are too late realized by wine companies or beverage selling enterprises, then problems are very close and are difficult to withstand.

The authors would like to thank Mr. Jean Chagnon and Mr. R. Degré, Lallemand Inc., for valuable discussions and critical reading of the manuscript. 


\section{References}

[1] K. Esser (ed.), The Mycota: Physiology and Genetics $X V$, 2nd edn. (Springer, 2018)

[2] M. Schmoll, C. Dattenböck (eds.), Gene Expression Systems in Fungi: Advancements and Applications (Springer, 2016)
[3] D. White, The Physiology and Biochemistry of Prokaryotes (Oxford University Press, 2011)

[4] P. Barbieri, Eur. Soc. Rev. 25, 621 (2009)

[5] A. Kalleberg, Work a. Occup. 30, 154 (2003)

[6] Anonymous, Types of flexible working, https:// www.nibusinessinfo.co.uk/content/ 